\title{
透析中の災害時の行動訓練を試みて 一所要時間の短縮一
}

依田典子尾首和代桐田由美子勝野浩* 立正佼成会附属佼成病院腎センター 同内科*

key words : 避難訓練, 回路切断，所要時間短縮

〈要旨〉

透析患者 15 名を対象に, 血液回路を切断後, 避難するという訓練を計 8 回施行し, 時間も測定した。また, 訓練前 後にアンケート調査を行い, 訓練の効果の一つの指標とした。午の結果, 訓練を重ねたことにより, 避難時間の短縮 がみられた。また，アンケートによると，訓練前，災害時の対処の仕方がわからない患者が $66 \%$ を占めたが，訓練後 は 8\%へと改善された。訓練前後の血圧の変動については，普段の透析前後と訓練前後のデータ分析によると，平均 値の比較においては, 有意差はなかった。今回の訓練を通し，行動レベルでの継続的な訓練の必要性と有効性が証明 された。

\section{Emergency drills for dialysis patients}

Noriko Yoda, Kazuyo Okubi, Yumiko Kirita, Hiroshi Katsuno*

Dialysis Unit of Kosei General Hospital ; Department of Internal Medicine, Kosei General Hospital*

Dialysis patients should be drilled in how to handle emergencies. We have conducted such drills at our hospital. Fifteen dialysis patients participated in these drills. We took them off dialysis 8 times in order to evacuate them during these simulated emergencies. After re-connecting the dialysis equipment, we recorded the length of time required for evacuation to a safe place.

The results of these tests showed that the time required by the patients became progressively shorter. This type of drill was thus demonstrated to be very beneficial for dialysis patients in the event of their needing to be evacuated from the hospital for any reason.

\section{緒言}

さまざまな自然災害を事前に予測することは，現在の 科学ではまだまだ困難な状況にある。世界各地で大きな 災害が発生し，被害状況の報道を目にする度に，これが 透析中の事故であったらと背筋の寒くなる思いである。

災害時, 透析施設においての避難活動は患者と器械が 直接つながっている状態であるため，単なる誘導だけで なく，避難前の対処が重要になってくる。

そこで，当施設でも災害時に被害を最小限に食い止め ることができるよう，1昨年に災害時行動マニュアルを 作成した。

しかし，スタッフ・患者共に内容が浸透していなかっ たため,さらに行動レベルでの対処の仕方を考察してみ
た。

一般に透析施設での緊急処置は 2 通りの方法がある。 1 つは，時間的余裕がある場合で全員返血する方法，も う 1 つは，時間的余裕がなく一刻を争う場合の血液回路 を切断する方法である。

血液回路を切断する方法は，全員返血する方法に比べ， 患者の積極的参加が必要となり，日頃の訓練が，災害時 に大きく影響してくると思われる。そこで，検討を加え た結果, 安全性を確認した上で, 静脈ラインまで返血後 に血液回路を切断し避難する訓練を施行した。

対象

実際の避難訓練への参加者は，社会復㷌し，普段の透 析経過が順調で, 止血完了時間 30 分以内, 透析終了後 1

依田 典子 立正佼成会附属佼成病院腎センター † 164 中野区弥生町 5-25-15 (03-3383-1281)

〔受付: 平成 3 年 10 月 7 日, 受理：平成 3 年 11 月 22 日〕 


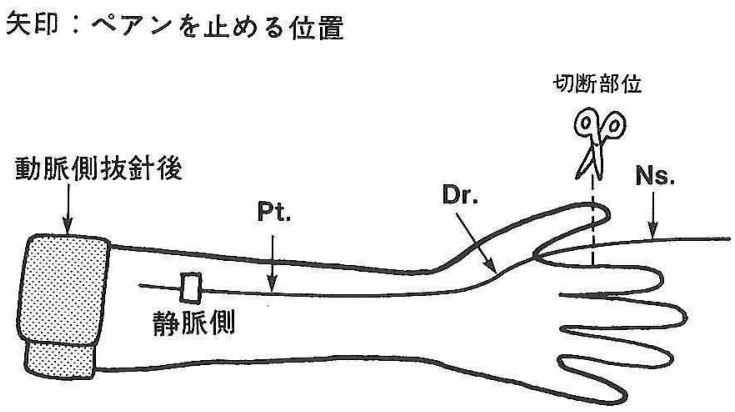

図 1 第 1 回目の回路切断方法

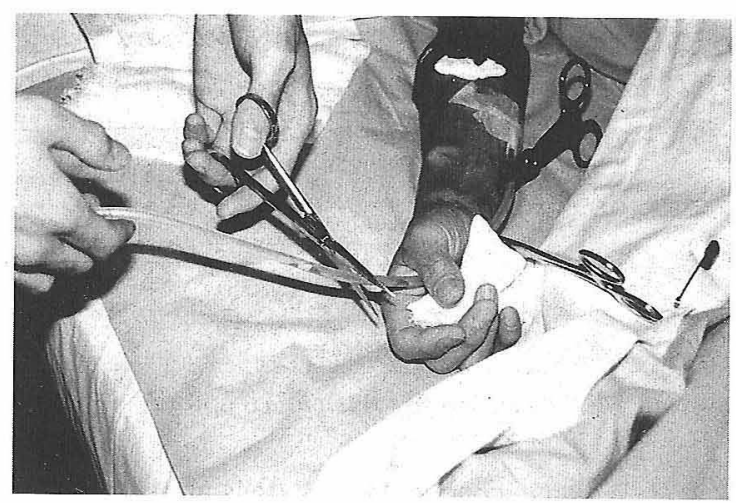

図 2 透析ラインの切断

時間以内に帰宅可能な患者を選んで行った。

対象患者は 15 名（男性 4 名, 女性 11 名）で, 年齢は 34 歳〜 72 歳 (平均 54.4 歳) であった。

\section{方法}

1。訓練前アンケート調查。

2。災害時, ライン切断想定し，スタッフがモデル となり、デモンストレーションを行う（回転ポンプの止 め方, ペアンの止め方, および止める位置, 避難方法, 非常袋の内容，避難場所について説明する)。

3.避難訓練を行うことを, 患者の同意を得た上で, スタッフの使用しているペアン (Skidmore $15 \mathrm{~cm}$ ) にて 練習を行ったが，1名は慢性関節りウマチによる手指の 機能低下，1名は上肢の筋力低下にて使用できず，患者 用ペアンとして，チューブ・クランプ (バイオ・インター ナショナル製）に変更した。 以後，全ての患者に拈いて 同製品にて訓練を行った。

4. 透析終了時間の同じ患者数名を抽出し, 訓練をし た.

\section{1) 第 1 回目の訓練方法}

(1)普段通り動脈側を抜針する。この時の止血用バンド は，ストッキング・ガーターを使用する。

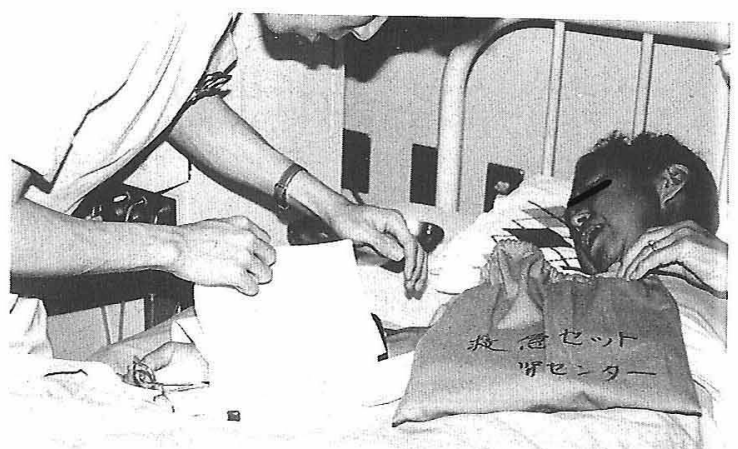

図 3 マンシェットによるラインの固定

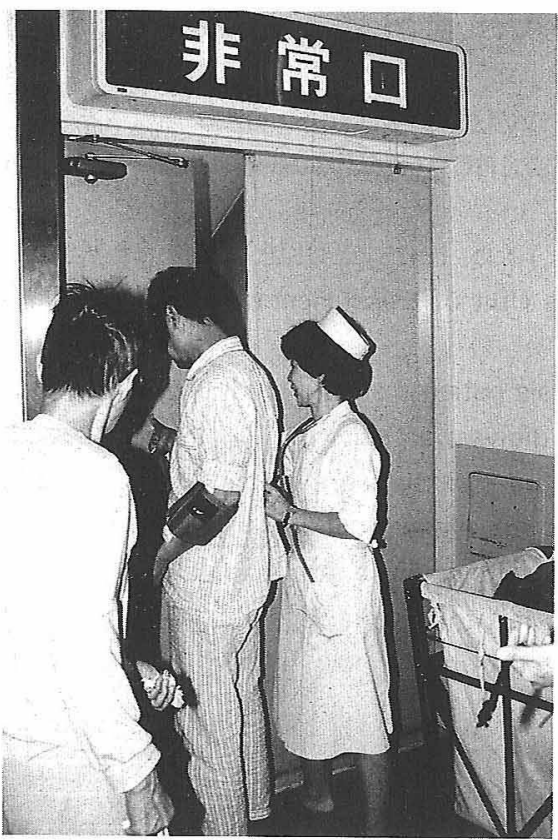

図 4 避難誘導

(2)通常通りに返血。

(3)患者の手の平の位置で医師にペアンを止めてもらう と同時に，患者は針先より約 $10 \mathrm{~cm}$ の所を，返血者は医 師のペアンの位置から, 約 $10 \mathrm{~cm}$ の所を, 止める(図 1)。

(4)患者全員のラインをペアンで止め終わった時点で, 一人の看護婦が医師と返血者のペアンとの中間点を次々 に切断していく(図 2).

(5)返血者が各ベッドに設置してある非常袋の中よりマ ンシェットを出し，ラインを固定していく（図 3 ).

(6)患者に非常袋を持ってもらい，同じ階の非常階段ま で避難する（約 $25 \mathrm{~m}$ ) (図 4)。 
知印：ペアンを止める位置

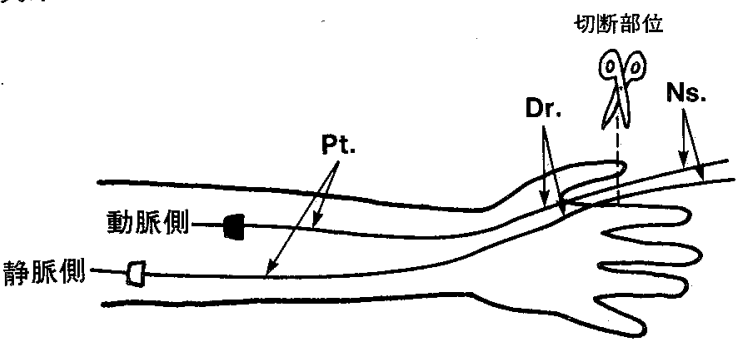

図 5 第 2，3，4回目の回路切断方法

(7)ラインを切断し始めた時点から，全員の避難完了ま での時間を測定する。

(8)終了後，血圧を測定する.

2 ）第 $2 \cdot 3 \cdot 4$ 回目の訓練方法

第 1 回目の訓練施行後，動脈側を切って返血してみた 方が実際に即していると思われたため方法を変更した。

(1)回転ポンプを止め, 動脈側のラインの針先より約 10 $\mathrm{cm}$ の所を患者に，手の平の位置で医師にペアンを止め てもらい，そこから約 $20 \mathrm{~cm}$ の所を返血者が止める。医 師が医師と返血者のペアンの中間点を消毒後，清潔な直 剪にて切断する（図 5 )。

(2)その後，普段の手順通りに返血する.

(3)静脈側ライン処理方法より，第 1 回目に準ずる。

5.さらに条件を統一し，4回訓練を施行し，時間測 定を行う。

〔条件〕：(1)四肢の機能障害がない患者を対象とする。 (2)患者とスタッフを同一人数（各4名）とする。(3)なる ベく同一患者が，2回ずつ訓練を行うようにする。

1) 方法
(1)〜3)は第 1 回目の訓練方法に準ずる.

(4) 4 人目の返血者がペアンを止めた時点で, 1 人目の 返血者がストップ・ウォッチを押し，そして，一斉に医 師の止めた位置と返血者のペアンの中間地点を消毒後, 切断する。

(5)患者のベッド・サイドに常備している非常袋を取っ てもらい，返血者がマンシェットを取り出し固定する。

(6)患者と共に非常階段まで避難する。

(7)最後の患者が階段（約 $25 \mathrm{~m}$ ) に到着し終わった時点 での時間を測定する。

8)㷌室後，血圧测定をする。

6. 訓練後, アンケート調査する。

7 。条件統一後の方法による訓練に参加した 10 名の患 者（延べ 16 名）の訓練施行前後の収縮期血圧について， 平均值・標準偏差・不偏分散を出す。

同 10 名について，訓練を施行した初日より，前 5 回の 透析に遡り，終了前後の収縮期血圧のデー夕を収集し， 処理を行う。

それらを二標本の母平均値の差の検定において比較し た。

\section{結果}

1. 透析時間の同じ患者による結果（表 1 ）

2 . 条件統一後の方法による結果（表 2)

3. 施行前後のアンケート結果（表 $3-1,3-2$ )

4. 条件統一後のデー夕分析（表 4)

\section{考察}

透析中の避難訓練ほ，出血や失血の危険性が高く，ほ とんどの透析施設に抒いての訓練方法は，スタッフによ るオリエンテーションおよびデモンストレーションで終 わってしまうことが多かったようである。

表 1 透析時間の同じ患者による結果

\begin{tabular}{|c|c|c|c|c|c|c|c|}
\hline 訓 & 練 & 回 & 数 & 第 1 回 & 第 2 回 & 第 3 回 & 第 4 回 \\
\hline 患 & & & 数 & 6 & 5 & 4 & 6 \\
\hline ス & 夕 & 7 & 数 & 4 & 5 & 6 & 4 \\
\hline 所 & 要 & 時 & 間 & 5 分 40 秒 & 5 分 35 秒 & 5 分 & 13 分 39 秒 \\
\hline \multicolumn{4}{|c|}{ 患者 1 名当りの平均所要時間 } & 56.7 秒 & 67 秒 & 75 秒 & 136.5 秒 \\
\hline \multirow{5}{*}{ 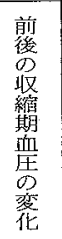 } & \multicolumn{3}{|c|}{ 上昇 $\quad(2 \sim 20 \mathrm{mmHg})$} & 3 & 2 & 2 & 3 \\
\hline & \multicolumn{3}{|c|}{$(20 \sim 40 \mathrm{mmHg})$} & 1 & 1 & & \\
\hline & \multicolumn{3}{|c|}{$(40 \sim 60 \mathrm{mmHg})$} & 2 & 1 & & \\
\hline & \multicolumn{3}{|c|}{ 変動なし } & & & 2 & 2 \\
\hline & \multicolumn{3}{|c|}{ 下降 $(-1 \sim-10 \mathrm{mmHg})$} & & 1 & & 1 \\
\hline
\end{tabular}

* 第 4 回目は，スタッフ間で方法が統一されておらず，最初に返血終わった 2 名が， さらに残り 2 名の返血を施行する予定が，てのまま 3 階から 1 階まで避難した後に 返血した時間 
表 2 条件統一後の方法による結果

\begin{tabular}{|c|c|c|c|c|c|c|c|}
\hline 訓 & 練 & 回 & 数 & 第 1 回 & 第 2 回 & 第 3 回 & 第 4 回 \\
\hline 患 & & & 数 & 4 & 4 & 4 & 4 \\
\hline ス & 夕 & フ & 数 & 4 & 4 & 4 & 4 \\
\hline 所 & 要 & 時 & 間 & 2 分 23 秒 & 1 分 22 秒 & 2 分 12 秒 & 1 分 52 秒 \\
\hline \multicolumn{4}{|c|}{ 患者 1 名当りの平均所要時間 } & 35.8 秒 & 22 秒 & 33 秒 & 28 秒 \\
\hline \multirow{6}{*}{$\begin{array}{l}\text { 前 } \\
\text { 後 } \\
\text { 収 } \\
\text { 摍 } \\
\text { 䐓 } \\
\text { 监 } \\
\text { 変 } \\
\text { 炛 }\end{array}$} & \multicolumn{3}{|c|}{ 上昇 $\quad(2 \sim 20 \mathrm{mmHg})$} & 2 & 2 & 2 & 2 \\
\hline & \multicolumn{3}{|c|}{$(20 \sim 40 \mathrm{mmHg})$} & 1 & 1 & 1 & 1 \\
\hline & \multicolumn{3}{|c|}{$(40 \sim 60 \mathrm{mmHg})$} & & & & \\
\hline & \multicolumn{3}{|c|}{ 変動なし } & & & & 1 \\
\hline & \multicolumn{3}{|c|}{ 下降 $(-1 \sim-10 \mathrm{mmHg})$} & 1 & & 1 & \\
\hline & \multicolumn{3}{|c|}{$(-11 \sim-20 \mathrm{mmHg})$} & & 1 & & \\
\hline
\end{tabular}

* 第 1 回目において 1 名 $\mathrm{BP}=160 / 104 \mathrm{mmHg}$ より $\mathrm{BP}=204 / 120 \mathrm{mmHg}$ と上昇した ため,アダラート 1 Cap. 内服する.

表 3-1 訓練前後のアンケート調查結果：その 1

\begin{tabular}{|c|c|c|c|c|}
\hline & & \multicolumn{2}{|c|}{ 訓練前 } & 訓練後 \\
\hline \multicolumn{2}{|l|}{ (1)回収率 } & \multicolumn{2}{|c|}{$100 \%$} & $100 \%$ \\
\hline \multirow[t]{2}{*}{ (2)内訳 } & 患者数 & \multicolumn{2}{|c|}{15 名 } & 15 名 \\
\hline & スタッフ & 7 名 & $\begin{array}{l}\text { 看護婦 } 4 \text { 名 } \\
\text { (研修生 } 1 \text { 名含む) } \\
\text { 臨床工学技士 } 2 \text { 名 } \\
\text { 看護助手 } 1 \text { 名 }\end{array}$ & . \\
\hline \multicolumn{2}{|l|}{ アンケート項目 } & 患者 & スタッフ & 患者 \\
\hline \multirow{3}{*}{ (3)災害時，最初に対処すること } & わかる & $3(20 \%)$ & $3(43 \%)$ & $11(73 \%)$ \\
\hline & 少しわかる & $2(13 \%)$ & $4(27 \%)$ & $3(20 \%)$ \\
\hline & わからない & $10(66 \%)$ & $1(14 \%)$ & $1(6 \%)$ \\
\hline \multirow[t]{2}{*}{ (4)当病院における避難場所 } & わかる & 0 & $14(93 \%)$ & $14(93 \%)$ \\
\hline & わからない & $15(100 \%)$ & $1(6 \%)$ & $1(6 \%)$ \\
\hline \multirow[t]{3}{*}{ (5)回転ポンプについて } & わかる & $2(13 \%)$ & & $10(66 \%)$ \\
\hline & 自信ないがわかる & $1(6 \%)$ & & 0 \\
\hline & わからない & $12(80 \%)$ & & $5(33 \%)$ \\
\hline \multirow[t]{3}{*}{ (6)ペアンについて } & わかる & $4(26 \%)$ & & $12(80 \%)$ \\
\hline & 自信ないがわかる & 0 & & 0 \\
\hline & わからない & $11(73 \%)$ & & $3(20 \%)$ \\
\hline
\end{tabular}

当施設でも, 昨年度, 避難訓練として, スタッフによ るオリエンテーションおよびデモンストレーションを 行った。しかし，今回，訓練前に収集したアンケートで は，災害時，最初に対処しなければならない行動がわか らないと答えた人は，全体の $66 \%$ ，高比率を占め，実 際訓練をしなければ効果が期待できないと考えられた。

また，スタッフのなかでも新人や研修生など経験の浅 い人などでも，わからないと答えた人が，約半数いた。
緊急時の対処の仕方には，返血する方法と回路切断の 方法があるが，八亀ら"によると，返血体制よりは，回路 切断のほうが，より適切であったと結論づけている。こ のことから，今回の訓練においては，回路切断時の必要 最小限の行動の仕方（回転ポンプを止め，ペアンで動・ 静脈ラインを止めるということ）について，主に焦点を 当てて訓練を行った.

アンケートによると, 訓練前, 回転ポンプについてわ 
表 3-2 訓練前後のアンケート調査結果：その 2

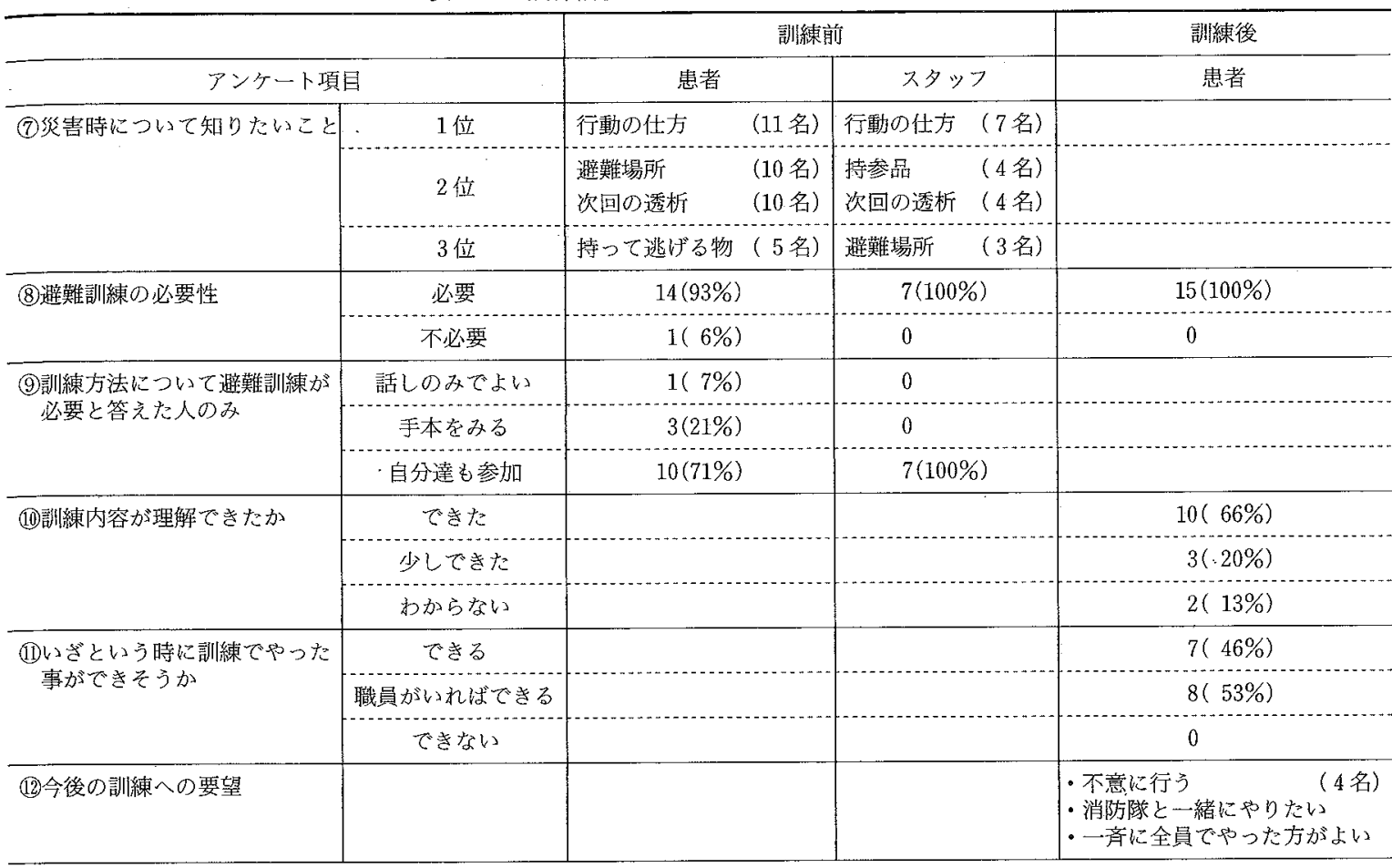

表 4 条件統一後の結果のデー夕分析

\begin{tabular}{c|c|c}
\hline & $\begin{array}{c}\text { 訓練に関係ない前 } \\
5 \text { 回分のデータ }\end{array}$ & $\begin{array}{c}\text { 訪練した } \\
16 \text { 回分のデータ }\end{array}$ \\
\hline 平均值 & 12.04 & 11.25 \\
\hline 標準偏差 & 14.52 & 15.08 \\
\hline 不偏分散 & 215.37 & 242.60 \\
\hline $\begin{array}{l}2 \text { 標本の母平均の差 } \\
\text { の検定 ( } \mathrm{t} \text { 検定) }\end{array}$ & $\begin{array}{l}\mathrm{t}=0.18 \text { (自由度 } 64) \\
\mathrm{t}<0.05 \\
\mathrm{t} \text { 分布表より有意差なし }\end{array}$ \\
\hline
\end{tabular}

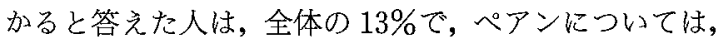
26\%にしかすぎなかったが，訓練後は前者については $66 \%$ ，後者については $80 \%$ と理解度が，増加した。

また，今回の訓練を総合的に理解できた人は全体の 66\%であり，災害時，実際に行動することができそうだ と答えた人は，職員の指示があればできるという人も含 めれば，92\%と高率を占めた。これらから，実際に患者 自身に訓練に参加してもらうことの有効性を痛感させら れた。今後は，理解できていない人に対し，理解度を高 める方法を検討していく必要があると考える。

今回の 8 回の訓練のうち, 後半 4 回については条件を ほほ同一にしているため，所要時間の比較検討について は可能だと思われる。
回数を重ねたことにより,時間の短縮がみられており, 継続した訓練の必要性と有効性が証明されたと考光る。

青森病院では, 綿密な計画の上, 年 2 回以上の防災訓 練を実施しており，それぞれの分担を決めてあるため， 日本海中部沖地震（震度 $4 \sim 5$ ）という大地震の際にも, 冷静で機敏な行動をとれだ2)とのことである。また，東京 消防庁によっても災害時の任務分担の必要性が指摘され ている゙ ことから，今後はスタッフ一人一人の役割を明 確化し，常に万一に備え，それらを室内に揭示しておく ことが必要ではないかと考光る。

訓練前後の血圧の変動については，血圧上昇する者が 多かったように思われる，だが，普段の透析前後と訓練 前後のデー夕分析によると，平均值の比較においては， 2 標本の母平均值の検定において，有意差はなかった。 しかし，1名降圧剤が必要になった。また，災害時には 訓練の時とは違い，避難行程も長く，精神的動摇も考光 られることから,各ベッドに設置してある非常袋の他に， 降圧片もべッド・サイドに用意しておく必要があると思 われた。そして，その他に抜針後に使用する消毒薬を入 れておく必要があると考える。

全ての訓練終了後のアンケートでは, $100 \%$ のが自分 達も参加する避難訓練の継続が必要だと認めており，今 後は不意に行ったり消防隊の人も含めて行いたいなどの 
積極的な意見が聞かれるようになった。

何事に対しても他人任せという依存的態度をとりがち な透析患者 ${ }^{4)} と っ て ，$ 自分もやらなくてはという意識 を持ち始めたことは，大きく評価できると思われる。

\section{結語}

我々は，重度の炎害時の対処の仕方を中心に訓練を 行ったが，今後は透析持続可能な場合や，返血をするこ とが可能な場合をも含めた総合的な訓練方法を検討して いくことが必要であると思う。

本論文の要旨は第 36 回日本透析療法学会 (神戸, 1991 年 7
月）に仍いて発表した。

\section{文献}

1）八亀和枝：人工透析中に扔ける火災発生時の避難方 法について。日本医科大学看護研究発表会録 11-12, 142,1988

2）地震と看護。日本看護協会・青森県支部 40,1984

3）職場の地震対策。東京消防庁 40,1987

4) 柴垣昌功：透析患者の看護。第 2 版, 医学書院, 東 京, 199，1984 